\title{
Analisis Produksi dan Efisiensi Alokatif Usahatani Lada di Desa Ameroro Kecamatan Tinondo Kabupaten Kolaka Timur
}

Nursalam $^{\mathrm{a}}$

${ }^{a}$ Fakultas Pertanian Perikanan dan Peternakan, Universitas Sembilanbelas November Kolaka,Kolaka-Sulawesi Tenggara, Indonesia.Email: noershalam@gmail.com

\section{Article Info}

\section{Article history:}

Received 15 Juni 2020

Received in revised form 7 Juli 2020

Accepted 20 Juli 2020

DOI:

https://doi.org/10.32938/ag.v5i3.1043 Keywords:

Produksi

Usahatani Lada

Efisiensi Alokatif

Cobb-Douglas

\begin{abstract}
Abstrak
Penelitian ini bertujuan untuk menganalisis faktor-faktor yang mempengaruhi produksi dan efisiensi alokatif usahatani lada Penelitian in dilaksanakan di Desa Ameroro Kecamatan Tinondo Kabupaten Kolaka Timur, penentuan lokasi dilakukan secara sengaja (purposive).Teknik penentuan sampel dalam penelitian ini menggunakan simple random sampling dan ditentukan dengan menggunakan rumus slovin sehingga diperoleh jumlah responden sebesar $60 \mathrm{KK}$. Penelitian ini dilaksanakan sejak Bulan Desember 2018 sampai dengan Bulan April 2019. Adapun jenis analisis data yang digunakan adalah regresi linear berganda dan efisiensi alokatif, model yang digunakan adalah persamaan fungsi produksi cobb-douglas.Hasil penelitian menunjukkan bahwa secara simultan atau bersama-sama (uji F) terdapat pengaruh yang signifikan terhadap produksi lada. Dengan nilai adjusted $\mathrm{R}^{2}$ adalah sebesar 0.799 . Hal ini berarti sebesar $79.9 \%$, produksi lada dijelaskan oleh luas lahan $\left(\mathrm{X}_{1}\right)$, tenaga kerja $\left(\mathrm{X}_{2}\right)$, pupuk phonska $\left(\mathrm{X}_{3}\right)$, dan pestisida $\left(\mathrm{X}_{4}\right)$. Berdasarkan $\mathrm{Uji}$ t, diperoleh hasil bahwa faktor produksi luas lahan, tenaga kerja, pupuk phonska dan pestisida berpengaruh nyata terhadap produksi lada. Berdasarkan hasil analisis efisiensi alokatif diketahui keempat faktor produksi : luas lahan, tenaga kerja, pupuk phonska, dan pestisida mempunyai nilai NPMx/Px lebih besar 1 yang artinya belum efisien sehingga perlu penambahan input untuk menghasilkan output yang selebih besar.
\end{abstract}

\section{Pendahuluan}

Lada merupakan salah satu komoditas ekspor perkebunan yang mempunyai arti penting dalam penerimaan devisa Negara. Salah satu komoditas yang menjadi unggulan dan mempunyai potensi yang besar dalam pertumbuhan ekonomi Indonesia adalah lada. Lada merupakan komoditas perkebunan dar Indonesia yang diperjual-belikan ke Eropa melalui Arabia dan Persia. Indonesia dikenal dengan 2 jenis lada yaitu lada hitam dari Lampung dan lada putih dari Bangka Belitung. Potensi komoditas lada bisa dilihat dengan mempunyai kenaikan produksi $1,75 \%$ setiap tahunnya. Indonesia sendiri memiliki pangsa pasar sekitar 35 persen dan pertumbuhan produksi lada dari produsen lainnya yang juga semakin meningkat. Hal ini berarti peluang Indonesia sangat besar dalam perdagangan dan bisnis lada (Ditjenbun, 2014). Budidaya tanaman lada di Indonesia tersebar hampir disemua provinsi. Sepuluh provinsi dengan luas areal dan produksi tertinggi lada di Indonesia pada tahun 2015 dapat dilihat pada Tabe

Tabel 1. Sepuluh Propinsi dengan Luas Areal dan Produksi Tertinggi Tanaman Lada di Indonesia Tahun 2015.

\begin{tabular}{lccc}
\hline \multicolumn{1}{c}{ Propinsi } & $\begin{array}{c}\text { Luas Areal } \\
(\mathrm{Ha})\end{array}$ & $\begin{array}{c}\text { Produksi } \\
\text { (Ton) }\end{array}$ & $\begin{array}{c}\text { Produktivitas } \\
\text { (Ton/Ha) }\end{array}$ \\
\hline Kepulauan Bangka Belitung & 48.408 & 31.896 & 0,66 \\
Lampung & 45.828 & 14.848 & 0,32 \\
Sulawesi Selatan & 14.335 & 5.092 & 0,36 \\
Sulawesi Tenggara & 14.220 & 5.547 & 0,39 \\
Sumatra Selatan & 11.325 & 8.776 & 0,77 \\
Kalimantan Timur & 9.639 & 6.968 & 0,72 \\
Kalimantan Barat & 7.938 & 3.657 & 0,46 \\
Bengkulu & 3.717 & 1.963 & 0,53 \\
Jawa Barat & 2.412 & 814 & 0,34 \\
Jawa Tengah & 1.950 & 505 & 0,36 \\
\hline Total & $\mathbf{1 5 9 . 7 7 2}$ & $\mathbf{8 0 . 0 6 4}$ & $\mathbf{4 , 8 1}$ \\
\hline
\end{tabular}

Sumber :Direktorat Jenderal Perkebunan, 2015

Tabel 1 menunjukkan bahwa produktivitas lada di sepuluh provinsi di Indonesia dengan produktivitas pada tahun 2015 sebesar 4,81 ton/ha. Dari keterangan tersebut menunjukkan peningkatan produktivitas yang tidak terlalu tinggi dibandingkan dengan provinsi lain, karena adanya kelemahan dan kendala yang dihadapi dalam budidaya tanaman lada.Salah satu upaya untuk menanggulangi berbagai permasalahan pada usahatani lada adalah menggunakan teknologi yang lebih baik.Provinsi Sulawesi Tenggara berada pada urutan ke empat dengan luas areal 14.220 hektar, dengan jumlah produksi sebesar 5.547 ton. Produktivitas lada di Sulawesi Tenggara masih tergolong rendah (rata-rata 0,39 ton/ha) jika dibandingkan dengan produktivitas lada di Sumatra Selatan (ratarata 0,77 ton/ha, Direktorat Jenderal Perkebunan (2015). Ini disebabkan oleh beberapa faktor antara lain: (1). Tingkat kesuburan tanah yang umumnya rendah karena didominasi podsolik merah kuning, (2). Pengelolaan tanaman budidaya yang dilakukan belum optimal karena masih dalam bentuk perkebunan rakyat, dan (3). Pengetahuan petani dalam penerapan teknik budidaya serta pemilik modal masih rendah, Sahara, dkk (2004)

Kabupaten Kolaka Timur adalah kabupaten yang memiliki luas panen dan produksi yang cukup besar, di Sulawesi Tenggara dengan jumlah produksi 584 ton/ha dan luas panen 3.565 hektar.Jika dilihat dari sisi produktivitas, Kabupaten Kolaka Timur memiliki tingkat produktivitas yang rendah. Menurut Direktora Jenderal Perkebunan (2015), produksi potensial tanaman lada khususnya Kabupaten Kolaka Timur belum mencapai hasil maksimal. Produksi lada secara kualitatif maupun kuantitatif ditentukan oleh beberapa faktor antara lain biaya (modal) yang dikorbankan untuk usahatani. Oleh karena itu setiap penggunaan modal dalam usahatani harus dapat memberikan keuntungan pada pemiliknya. Dalam usahatani lada ada beberapa hal yang perlu diperhatikan agar bisa mencapai produksi yang optimal untuk memperoleh keuntungan maksimal diantaranya adalah penggunaan faktor produksi. Oleh karena itu alokas penggunaan faktor produksi yang optimal perlu dilakukan untuk mencapai efisiensi alokatif sehingga diharapkan dapat memperoleh keuntungan yang maksimal.

Permasalahan produksi lada yang masih rendah di Desa Ameroro Kecamatan Tinondo diduga berkaitan erat dengan persoalan efisiensi penggunaan input, alokasi penggunaan input diduga masih belum optimal. Salah satu indikator dari efisiensi adalah jika sejumlah output tertentu dapat dihasilkan dengan menggunakan sejumlah kombinasi input yang lebih sedikit atau kombinasi input-input tertentu dapat meminimumkan biaya produksi tanpa mengurangi output yang dihasilkan. Efisiensi alokatif dapat diformulasikan setelah mengetahui faktor-faktor yang mempengaruhi produksi.

Faktor-faktor produksi yang mempengaruhi produksi lada dapat diketahui dengan estimasi terhadap input-input yang digunakan oleh petani dalam fungs produksi. Fungsi produksi dapat menjelaskan penggunaan input-input yang mempengaruhi produksi, input yang diduga mempengaruhi produksi diantaranya pemanfaatan luas lahan, tenaga kerja, pupuk phonska dan pestisida. Efisiensi alokatif dapat diketahui dari penggunaan input yang secara signifikan mempengaruhi produksi lada, efisiensi alokatif akan tercapai ketika nilai produk marginal dari penggunaan input sama dengan harga input tesebut.

\section{Metode}

Penelitian ini telah telah dilaksanakan sejak bulan Desember 2018 sampai dengan Bulan April 2019.Penentuan daerah penelitian dilakukan secara purposive (sengaja) dengan melihat daerah yang menjadi Sentral produksi lada di Kabupaten Kolaka Timur. Data-data dalam penelitian ini diperoleh melalui proses survey dan wawancara secara terstruktur dengan menggunakan kuesioner. Populasi petani lada di Desa Ameroro Kecamatan Tinondo Kabupaten Kolaka berjumlah 150 KK.Jumlah sampel ditentukan dengan menggunakan rumus slovin (Hasan, 2002).

$\mathrm{n}=\frac{N}{1+N \cdot e^{2}}$

Dimana

n : Jumlah sampel

$\mathrm{N} \quad$ : Jumlah populasi petani $(150 \mathrm{KK})$

e : Tingkat kesalahan (10\%)

sehingga diperoleh jumlah sampel dalam penelitian ini adalah $60 \mathrm{KK}$ petani lada.

\section{Analisis Data}

Untuk mengetahui faktor-faktor yang mempengaruhi produksi lada di Desa Ameroro Kecamatan Tinondo Kabupaten Kolaka Timur menggunakan fungsi produksi Cobb Douglas sebagai berikut:

$\mathrm{Y}=\beta_{0} \mathrm{X}_{1}^{\mathrm{b} 1}, \mathrm{X}_{2}^{\mathrm{b} 2}, \mathrm{X}_{3}^{\mathrm{b} 3}, \mathrm{X}_{4}^{\mathrm{b} 4}, \mathrm{e}$

Selanjutnya untuk memudahkan perhitungan estimasi persamaan diubah dalam bentuk Ln (logaritma natural) sehingga menjadi:

$\operatorname{Ln} \mathrm{Y}=\ln \alpha+\mathrm{b}_{1} \ln \mathrm{X}_{1}+\mathrm{b}_{2} \ln \mathrm{X}_{2}+\mathrm{b}_{3} \ln \mathrm{X}_{3}+\mathrm{b}_{4} \ln \mathrm{X}_{4}+\mu \ldots$

Keterangan:

\begin{tabular}{|c|c|}
\hline Y & $=$ Produksi lada $(\mathrm{kg})$ \\
\hline$\alpha$ & $=$ Nilai kostanta \\
\hline $\mathrm{b}_{1}, \mathrm{~b}_{2}, \mathrm{~b}_{3}, \mathrm{~b}_{4}, \mathrm{~b}_{5}$ & $=$ Koefisien regresi \\
\hline $\mathrm{X}_{1}$ & $=$ Luas lahan $(\mathrm{Ha})$ \\
\hline $\mathrm{X}_{2}$ & $=$ Tenaga Kerja $(\mathrm{HOK})$ \\
\hline $\mathrm{X}_{3}$ & $=$ Pupuk Phonska $(\mathrm{kg})$ \\
\hline $\mathrm{X}_{4}$ & $=$ pestisida (liter) \\
\hline 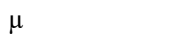 & $=$ Kesalahan pengganggu (error term) \\
\hline
\end{tabular}


Sedangkan untuk mengetahui efisiensi harga atau allokative efficiency menurut Soekartawi (2003), pada fungsi produksi Cobb-Douglas, maka b disebut dengan koefisien regresi yang sekaligus menggambarkan elastisitas produksi. Oleh karena itu, Nilai Produk Marjinal (NPM) faktor produksi X adalah:

$\mathrm{NPM}_{\mathrm{Xi}}=\frac{b \cdot Y \cdot P_{y}}{P_{x}}$

Keterangan:

$\mathrm{NPM}_{\mathrm{Xi}} \quad$ : Nilai produk marginal faktor produksi ke-i

b : Elastisitas produksi

Y $\quad$ : Produksi

$\mathrm{P}_{\mathrm{X}} \quad$ : Harga persatuan faktor produksi ke-i

Py $\quad$ : Harga produksi

NPMx sama dengan Px maka alokasi faktor-faktor produksi sudah efisien secara alokatif. Hal tersebut menunjukkan keuntungan yang maksimum atau penggunaan faktor produksinya sudah optimum. Dengan kriteria efisiensinya adalah sebagai berikut:

1. Apabila $\frac{N P M_{x}}{P_{x}}=1$ artinya penggunaan input produksi sudah efisien

2. Apabila $\frac{N P M_{x}}{P_{x}}>1$ artinya penggunaan input produkdi belum efisien atau terlalu sedikit seingga untuk mencapai efisiensi penggunaan input produksi perlu ditambah.

3. Apabila $\frac{N P M_{x}}{P_{x}}<1$ artinya penggunaan input produksi tidak efisien atau penggunaannya sudah melebihi batas optimum sehingga untuk mencapai efisensi input produksi perlu dikurangi.

\section{Hasil dan Pembahasan}

\subsection{Uji Asumsi Klasik}

Penggunaan uji asumsi klasik dapat memberikan kepastian terhadap persamaan regresi yang digunakan serta memiliki ketepatan dalam estimasi, tidak bias dan konsisten yang meliputi uji normalitas, multikolineritas dan heteroskedasitas sebagai berikut.

\section{1) Uji Normalitas Kolmogorov Smirnov}

Uji normalitas Kolmogorov Smirnov digunakan untuk mengetahui apakah nilai residual berdistribusi normal atau tidak, model regresi yang baik adalah memiliki nilai residual berdistribusi normal.Uji normalitas Kolmogorov Simirnov ini menggunakan aplikasi SPSS 21. Dengan asumsi bahwa jika nilai signifikansi $>0,05$ maka nilai residual berdistribusi normal.

Tabel 2. Hasil Uji Normalitas Kolmogorov Smirnov Pengaruh Faktor Produksi Terhadap Produksi Lada.

\begin{tabular}{llc}
\hline & & Residual \\
$\mathrm{N}$ & Mean & 60 \\
\hline Normal & Std. Deviation &, 0000000 \\
Parameters $^{a . b}$ & Absolute & 16,73240119 \\
Most Exstreme & Positive &, 155 \\
Differences & Negative &, 155 \\
Kolmogorov-Smirnov $Z$ & &,- 117 \\
Asymp. Sig. (2 tailed) & & 1,202 \\
\hline
\end{tabular}

a. Test distribution is Normal

b. Calculated from dat

Berdasarkan Tabel 2. Menunjukkan bahwa uji normallitas diketahui nilai signifikansi $0,111>0,05$ maka dapat disimpulkan bahwa nilai residual berdistribusi normal.

\section{2) Uji Multikolineritas}

Uji multikolineritas bertujuan untuk menguji apakah penggunaan model regresi ditemukan adanya korelasi antara variabel independen, Imam Gozali (2013). Metode yang dapat digunakan untuk melihat apakah terjadi multikolineritas adalah dengan melihat nilai tolerance dan VIF, dengan kriteria jika nilai tolerance $>0,10$ tidak terjadi multikolineritas sedangkan untuk nilai VIF $<10,00$ maka tidak terjadi multikolineritas.

Tabel 3, menunjukkan bahwa semua nilai variabel Tolerance lebih besar 0,10 dan nilai VIF kurang dari 10, sehingga dapat disimpulkan bahwa model regresi yang digunakan baik karena tidak ditemukan adanya multikolineritas antara variabel independen.

\section{3) Uji Heteroskedasitas}

Uji heteroskedasitas bertujuan untuk mengetahui apakah dalam model regresi terjadi ketidak samaan variansi dari residual satu pengamatan kepengamatan yang lain. Pengujian heteroskedasitas dilakukan dengan menggunakan uji Glejser dengan keputusan jika nilai signifikansi antara variabel independen dengan absolute residual $>$ dari 0,05 maka tidak terjadi heteroskedasitas, Gujarati (2003).

Dari Tabel 4. menunjukan bahwa nilai signifikansi antara variabel independen dengan absolute residual $>0,05$ maka dapat disimpulkan bahwa tidak terjadi Heteroskedasitas. Atau dengan kata lain model regresi dikatakan baik.

Tabel 3. Hasil Uji multikolineritas Pengaruh input Produksi terhadap Produksi Lada.

\begin{tabular}{|c|c|c|c|}
\hline No & Variabel & Tolerance & Keterangan \\
\hline 1 & Luas Lahan & 0,255 & 3,917Non Multikolineritas \\
\hline 2 & Tenaga Kerja & 0,297 & 3,370Non Multikolineritas \\
\hline 3 & Pupuk Phonska & 0,591 & 1,691 Non Multikolineritas \\
\hline 4 & Pestisida & 0,481 & 2,081 Non Multikolineritas \\
\hline
\end{tabular}

Tabel 4. Hasil Uji Heteroskedasitas Glejser Pengaruh Input Produksi Terhadap Produksi Lada.

\begin{tabular}{lcccrc}
\hline \multicolumn{1}{c}{ Model } & \multicolumn{2}{c}{$\begin{array}{c}\text { Unstandardized } \\
\text { Coefficients } \\
\text { Std. Error }\end{array}$} & $\begin{array}{c}\text { Standardized } \\
\text { Coefficients } \\
\text { Beta }\end{array}$ & $\mathrm{t}$ & Sig \\
\hline 1 (Constant) & 56,802 & 26,202 & & 2,168 &, 035 \\
Luas Lahan &, 076 &, 140 &, 138 &, 544 &, 589 \\
Tenaga Kerja &,- 172 &, 119 &,- 341 & $-1,447$ &, 154 \\
Pupuk Phonska &,- 072 &, 076 &,- 158 &,- 945 &, 349 \\
Pestisida &, 024 &, 085 &, 051 &, 276 &, 783 \\
\hline
\end{tabular}

\subsection{Uji Statistik}

Pengujian hipotesis faktor-faktor yang mempengaruhi produksi usahatan lada menggunakan analisis regresi linear berganda dengan menganalisis koefisien determinas $\left(\mathrm{R}^{2}\right)$, uji keragaman $(\mathrm{F})$ dan uji t pada tingkat kepercayaan $95 \%$ atau $\alpha 0,05$.

\section{1) Uji Koefisien Determinasi $\left(\mathbf{R}^{2}\right)$}

Uji koefisien determinasi menunjukkan seberapa besar variabel bebas menjelaskan hasil (multiple correlation coefficient) kisaran nilai $\mathrm{R}^{2}$ adalah 0 hingga1. Semakin mendekati nilai 1 maka semakin kuat variabel bebas memprediksikan variabel terikat. Berdasarkan data pada Tabel 5 menunjukkan bahwa nilai $\mathrm{R}^{2}$ adalah 0,799 atau 79,9\% yang berarti bahwa variabel bebas Luas lahan, Tenaga Kerja, Pupuk Phonska dan Pestisida dapat dijelaskan oleh keempat variabel tersebut, sedangkan $20,1 \%$ dijelaskan oleh variabel diluar dari modal.

\section{2) Pengaruh Secara Simultan (Uji F)}

Uji F digunakan untuk menyatakan bahwa variable independen yang terdiri dari Luas lahan tenaga kerja, pupuk phonska dan pestisida berpengaruh terhadap jumlah produksi usahatani lada. Pada Tabel 5. Menunjukkan bahwa dari hasil analisis berdasarkan uji $\mathrm{F}$ diperoleh nilai $\mathrm{F}_{\text {hitung }} 5,477>\mathrm{F}_{\text {tabel }}(2,788)$, artinya bahwa secara bersama-sama variabel independen terhadap variabel dependen berpengaruh secara signifikan.

\section{3) Pengaruh Secara Parsial (Uji t)}

Untuk mengetahui pengaruh masing-masing variabel independen terhadap variabel dependen maka digunakan uji t.

\section{- Luas Lahan $\left(\mathbf{X}_{1}\right)$}

Luas lahan usahatani merupakan faktor utama dalam meningkatkan jumlah produksi lada. Lahan diperlukan sebagai tempat budidaya tanaman sampai menghasilkan. Rata-rata penggunaan luas lahan yang digunakan oleh petani lada di Desa Ameroro Kecamatan Tinondo untuk kegiatan usahatani lada sebesar 1,50 Ha.

Hasil uji t statistik pada Tabel 5 di atas menunjukkan bahwa penggunaan luas lahan berpengaruh signifikan terhadap produksi usahatani lada pada tingkat kepercayaan $99 \%$ dengan p-value 0,00 lebih kecil dari $\alpha 0,01$. Nilai koefisien regresi yang diperoleh sebesar 1,135 dan bertanda positif. Hal ini menunjukkan bahwa setiap penambahan luas lahan garapan sebesar 1\% akan menambah produksi lada sebesar $1,135 \%$. Hal ini sesuai dengan penelitian yang dilakukan oleh Dewi Sahara (2004) dengan bertambahnya luas lahan budidaya yang diusahakan oleh petani maka semakin banyak produksi yang akan dihasilkan.

\section{- Tenaga Kerja $\left(\mathbf{X}_{2}\right)$}

Jenis tenaga kerja yang digunakan dalam kegiatan usahatani lada adalah tenaga kerja dalam dan luar keluarga, tenaga kerja tersebut digunakan dalam proses pemupukan, penyiangan, panen dan pasca panen. Rata-rata penggunaan tenaga kerja sebesar $81,08 \mathrm{HOK} / \mathrm{Ha}$.

Dalam penelitian ini variabel penggunaan tenaga kerja berpengaruh signifikan terhadap produksi usahatani lada. Hasil uji t statistik pada Tabel 5 di atas menunjukkan bahwa penggunaan tenaga kerja pada usahatani lada berpengaruh signifikan pada tingkat kepercayaan $90 \%$ dengan p-value sebesar 0,108 lebih kecil dari $\alpha 0,10$. Nilai koefisien regresi sebesar 0,270 dan bertanda positif, hal ini dapat menunjukkan bahwa setiap penambahan $1 \%$ tenaga kerja akan meningkatkan produksi lada sebesar $0,270 \%$ dengan asumsi variabel lain dianggap konstan. Hal ini sesuai dengan penelitian yang dilakukan oleh Andi Annisa Sulolipu (2016) penambahan jumlah tenaga kerja akan meningkatkan produksi lada yang dihasilkan.

\section{- Pupuk Phonska $\left(\mathrm{X}_{3}\right)$}

Jenis pupuk yang digunakan pada daerah penelitian adalah pupuk Phonska. Hasil uji t statistik pada Tabel 5 di atas menunjukkan bahwa penggunaan pupuk phonska yang digunakan pada usahatani lada berpengaruh tidak signifikan pada tingkat kepercayaan 95\% dengan p-value sebesar 0,170 lebih besar dari $\alpha 0,05$. namun memiliki nilai koefisien regresi sebesar 0,145 dan bertanda positif, hal ini dapat menunjukkan bahwa setiap penambahan $1 \%$ pupuk phonska akan meningkatkan produksi lada sebesar $0,145 \%$ dengan asumsi faktor produksi lain dianggap konstan. Hal ini sesuai dengan penelitian yang dilakukan oleh Yudi Zuriah Wirya Purba (2015) penambahan jumlah pupuk pada usahatani 
lada akan meningkatkan jumlah produksi. Secara umum penggunaan pupuk pada daerah penelitian belum optimal.

\section{- Pestisida $\left(\mathbf{X}_{4}\right)$}

Serangan hama, penyakit dan jamur pada tanaman lada dapat menurunkan produksi sehingga perlu penggunaan pestisida dalam rangka peningkatan produksi. Hasil uji t statistik pada Tabel 5 menunjukkan bawa penggunaan pestisida berpengaruh tidak signifikan terhadap produksi usahatni lada pada tingkat kepercayaan $95 \%$ dengan tingkat p-value 0,524 lebih besar dari $\alpha 0,05$. jumlah Penggunaan pestisida pada usahatani lada memiliki koefisien regresi sebesar 0,075 yang berarti bahwa setiap penambahan $1 \%$ pestisida akan meningkatkan produksi usahatani lada sebesar $0,075 \%$ dengan asumsi variabel lain dianggap konstan. Hal ini sesuai dengan penelitian Dewi Sahara dkk. (2004) bahwa pengunaan fungisida pada tanaman lada akan meningkatkan produksi

Tabel 5. Pengaruh Input Produksi Terhadap Produksi Lada

\begin{tabular}{lccc}
\hline Variabel & Koefisien Regresi & $\mathrm{t}_{\text {hitung }}$ & Sig \\
\hline Konstanta & 2,395 & $6,629 * * *$ & 0,000 \\
Ln Luas Lahan & 1,135 & $5,905^{* * *}$ & 0,000 \\
Ln Tenaga Kerja & 0,270 & $1,632^{* *}$ & 0,108 \\
Ln Pupuk Phonska & 0,145 & $1,389 *$ & 0,170 \\
Ln Pestisida & 0,075 & $-0,642$ & 0,524 \\
\hline R-Squared & 0,799 & & \\
$\mathrm{~F}_{\text {hitung }}$ & 5,477 & \\
$\mathrm{~F}_{\text {tabel }} \mathrm{l}$ & & \\
Sig & 2,788 & \\
$\mathrm{~N}$ & 0,000 & \\
Keterangan & 60 &
\end{tabular}

\section{4) Analisis Efisiensi alokatif}

Analisis efisiensi alokatif penggunaan input produksi pada usahatani lada dapat diketahui dengan menghitung rasio Nilai Produk Marginal (NPM) suatu faktor produksi dengan harga masing-masing faktor produksi Px (Soekartawi, 2002). Hasil analisis efisiensi alokatif faktor produksi usahatani lada dapat dilihat pada Tabel 6.

Tabel 6. Tingkat Efisiensi Alokatif pada Usahatani Lada

\begin{tabular}{lcccccccc}
\hline Variabel & $\beta$ & $\mathrm{Y}$ & $\mathrm{Py}$ & $\mathrm{Xi}$ & $\mathrm{Px}$ & $\mathrm{NPMx}$ & $\begin{array}{c}\text { NPMx } \\
\text { /Px }\end{array}$ & Ket \\
\hline Luas Lahan & 1,135 & 2702,45 & 37.000 & 1,504 & 25.000 & 301,833 & 1,21 & $\mathrm{BE}$ \\
Tenaga & 0,270 & 2702,45 & 37.000 & 81,07 & 80.000 & 333,014 & 4,16 & $\mathrm{BE}$ \\
Kerja & & & & & & & & \\
Pupuk & 0,140 & 2702,45 & 37.000 & 321,6 & 150.000 & 435282,68 & 2,9 & $\mathrm{BE}$ \\
Phonska & 0,075 & 2702,45 & 37.000 & 10,43 & 65.000 & 7443,4 & 1,11 & $\mathrm{BE}$ \\
Pestisida & 0,00
\end{tabular}

Berdasarkan Tabel 6 di atas menunjukkan bahwa penggunaan input-input produksi yaitu luas lahan, tenaga kerja, pupuk phonska dan pestisida pada usahatani lada mempunyai nilai NPMx/Px lebih besar dari satu yang artinya bahwa penggunaan keempat input produksi belum efisien. Hali ini berarti secara alokatif penggunaan lahan, tenaga kerja, pupuk phonska dan pestisida oleh petani dalam usahatani lada belum efisien, dengan demikian agar menjadi efisien secara alokatif maka faktor produksi harus ditambah.

Hal ini sesuai dengan hasil penelitian yang dilakukan oleh Yudi Zuriah Wirya Purba (2015), input produksi luas lahan dan tenaga kerja tidak efisien sedangkan pupuk dan pestisida sudah efisien. sedangkan penelitian yang dilakukan oleh Riana Safitri (2012) bahwa input produksi pupuk, pestisida, penyusutan alat dan tenaga kerja sudah efisien karena penggunaan input produksi pada usahatani lada sudah optimal berbanding terbalik dengan petani yang ada di desa penelitian saya dimana penggunaan input-input produksi belum optimal.

\section{Simpulan}

Peningkatan produksi lada dipengaruhi oleh faktor luas lahan dan tenaga kerja, berdasarkan uji statistik menunjukkan bahwa luas lahan dan tenaga kerja berpengaruh positif dan signifikan terhadap usahatani lada sedangkan penggunaan pupuk phonska dan pestisida berpengaruh tidak signifikan terhadap produksi lada. Produksi lada akan semakin meningkat jika ada penambahan input-input produksi. Sedangkan berdasarkan analisis efisiensi alokatif penggunaan input produksi pada usahatani lada belum efisien sehingga masih perlu penambahan input produksi agar supaya lebih efisien.

\section{Pustaka}

Solipu ,A.A.2016.Pengaruh Faktor-Faktor Produksi pada Usahatani Lada di Desa Swatani Kecamatan Rilau Ale Kabupaten Bulukumba.Jurnal ad'ministrate Vol. 3 Nomor 2 Hal. 95-106

Sahara, D. Yusuf, dan Sahardi. 2004. Pengaruh faktor produksi pada usaha tani lada di Sulawesi Tenggara. Jurnal Pengkajian dan Pengembangan Teknologi Pertanian, 7(2), 139-145.

Direktorat Jenderal Perkebunan. 2015. Statistik Perkebunan Indonesia Komoditas Lada 2015-2017. Departemen Pertanian. Jakarta
Direktorat Jenderal Perkebunan Kementerian Pertanian Republik Indonesia. 2014. Basic Data Ekspor Inpor Produk Pertanian Indonesia 2012-2016, Diakses pada tanggal 22 Februari 2019 dari https://database.pertanian go.id/eksim/index1.asp

Gozali I, 2013 Aplikasi Analisis Multivariate dengan Program IBM SPSS 21 Update PLS Regresi. Badan Penerbit Universitas Diponegoro. Semarang Gujarati, 2003. Ekonometrika Dasar. Terjemahan Erlangga. Jakarta

Hasan.2002. Skala Pengukuran Variabel-Variabel Penelitian. Penerbit Alvabeta Bandung

Riana S. 2012. Analisis Pendapatan dan efisiensi alokatif Usahatani Lada (Piper nigrum L) di Desa Batuah Kecamatan Loa Janan Kabupaten Kutai Kartanegara.Jurnal EPP Vol. 9 Nomor 1 Hal. 35-41

Soekartawi, 2003.Teori Ekonomi Produksi dengan Pokok Bahasan Analisis Fungsi Cobb-Douglash. CV. Rajawali. Jakarta

Purba,Y.Z.W., Mirza A. 2015.Optimalisasi Penggunaan Faktor Produksi Usaha Tani Lada di Lahan Bekas Tambang Kabupaten Bangka Provinsi Bangka Belitung.Prosiding Seminar Nasional Lahan Sub Obtimal. Palembang 